\title{
KEBERPIHAKAN PEMERINTAH KOTA JAMBI PADA MASYARAKAT MISKIN PERKOTAAN
}

\author{
Riri Maria Fatriani ${ }^{1}$, Makmun Wahid ${ }^{2}$, Ratna Dewi ${ }^{3}$ \\ ${ }^{1,2,3}$ Lecturer in Government Science at Jambi University \\ ririmariafatriani@unja.ac.id
}

\begin{abstract}
ABSTRAK
Penelitian ini mendeskripsikan dan menganalisis keberpihakan Pemerintah Kota Jambi dalam menjamin pendidikan dan kesehatan bagi masyarakat miskin perkotaan di kota Jambi. Untuk melihat berhasil tidaknya pemerintah menjalankan fungsinya tersebut, penelitian ini akan mencoba mengungkapnya melalui penyelenggaraan jaminan sosial kasus pelayanan pendidikan dan kesehatan di kawasan Tempat Pembuangan Akhir Sampah Talang Gulo, Kota Jambi. Studi ini menggunakan jenis penelitian kualitatif dengan menggunakan pendekatan studi kasus yang bersifat intrinsic case study bertujuan untuk mengetahui lebih mendalam tentang proses keberpihakan pemerintah Kota Jambi terhadap mereka yang selama ini jauh dari jangkauan program pemerintah. Adapun hasil dari penelitian ini adanya miskoordinasi antara sektor swasta, dan pemerintah dalam menyelenggarakan jaminan sosial. Penduduk miskin di Kota Jambi tidak mendapatkan jaminan sosial yang baik untuk menjalankan hidup dengan baik serta ada semacam budaya kemiskinan di Talang Gulo yang terlihat dari sebagian masyarakat miskin di kawasan tersebut berfikir hidupnya cukup dengan cara seperti sekarang atau dengan kata lain kemiskinan yang struktural. Temuan penelitian menggambarkan bahwa Negara telah gagal dalam menyelenggarakan jaminan sosial sebagai salah satu strategi untuk mengatasi masalah kesejahteraan masyarakat terutama bagi mereka yang hidup dibawah garis kemiskinan.
\end{abstract}

Kata kunci : Kemiskinan, Perkotaan, Jaminan Sosial

\begin{abstract}
This study describes and analyzes the alignments of the Jambi City Government to ensuring education and health for the urban poor society at Jambi city. To see whether or not the government has succeeded in carrying out those function, this research will try to reveal it through the implementation of social security in the case of education and health services in Talang Gulo's Final Waste Disposal Area, Jambi City. This study uses a type of qualitative research with case study approach that is intrinsic case study to find out more about the alignments of the Jambi City government to those who have been far from the reach of government programs. The results of this study are miscoordination between the private sector, and the government in organizing social security. The poor society in Jambi City do not get good social security to live a good life and there is a kind of poverty culture in Talang Gulo which can be seen from some of the poor communities in the region who think their lives are quite like now or in other words structural poverty. The research findings illustrate that the State has failed in organizing social security as a strategy to overcome the welfare problems of the community, especially for those who live below the poverty line.
\end{abstract}

Key words: Destitution, Urban, Social Security 


\section{Pendahuluan}

Penelitian ini bermaksud untuk menjelaskan sejauh mana keberpihakan pemerintah dalam menjamin pendidikan dan kesehatan bagi masyarakat miskin perkotaan di kota Jambi. Untuk melihat berhasil tidaknya pemerintah menjalankan fungsinya tersebut, penelitian ini akan mencoba mengungkapnya melalui kasus pelayanan pendidikan dan kemiskinan di kawasan Tempat Pembuangan Akhir Sampah Talang Gulo, kota Jambi.

Kasus ini menarik dijadikan arena kajian sekaligus ajang pembuktian dugaan peneliti yang setidaknya berangkat dari dua argumentasi. Pertama, kasus masyarakat miskin kota ini telah berulang kali menjadi perhatian pemerintah di berbagai negara. Kedua, kelompok masyarakat miskin kota seringkali jauh dari perhatian pemerintah. Keterbelakangan dalam segala hal, membuat mereka sulit mendapatkan layanan dari negara.

Dalam konteks bernegara, Indonesia menganut semangat negara kesejahteraan seperti yang dianut pula oleh negara modern lain di dunia. Semangat negara sejahtera itu setidaknya secara prosedural telah termanifestasi dalam dasar negara kita yakni: keadilan sosial bagi seluruh rakyat Indonesia. Norma inilah yang kemudian menjadi rambu-rambu bagi pemerintah untuk bekerja dan mengayomi semua golongan dalam masyarakat. Termasuk menjamin tegaknya pemerataan, dimana salah satu hal yang utama dari yang dimaksud tersebut yaitu kebebasan bagi siapapun untuk mendapatkan layanan pendidikan dan kesehatan. Hanya saja, negara melalui instrumennya (baca: pemerintah daerah) sering kali gagal dan terkesan abai dalam penegakan hak-hak sipil terutama yang berkaitan dengan kelompok minoritas miskin perkotaan. Sehingga, muncul kesan bahwa negara hanya dimiliki golongan kelas atas saja. Padahal dalam pandangan teori negara kesejahteraan, negara merupakan alat masyarakat secara keseluruhan, tidak berpihak serta harus selalu steril dari kepentingan kelas maupun kelompok tertentu (Paskarina, 2015). Karena itulah, konstruksi negara kesejahteraan yang menjunjung tinggi keadilan sosial tersebut, ternyata masih menyimpan masalah mendasar dalam praktiknya di berbagai daerah.

Kemunculan studi ini salah satunya dipicu oleh masalah mendasar itu, dimana semangat pemerataan dalam tubuh negara di Indonesia hanya indah dalam kata, tetapi buruk dalam rupa. Bagi studi ini, konsepsi negara ideal yang kita yakini hingga saat ini hanya menguntungkan kelas maupun kelompok tertentu saja. Ideologi negara kesejahteraan yang diinstalasi dalam format keadilan sosial, ternyata tidak dinikmati oleh segenap lapisan masyarakat. Seharusnya jika mengikuti nalar kesejahteraan, negara senantiasa bekerja di atas segala kepentingan masyarakat dan tidak memihak kepada salah satu kelompok mana pun dalam sebuah rezim demokratis. Artinya, pada tataran idealitas, negara seharusnya menjadi lembaga milik bersama semua anggota masyarakat. Dalam ungkapan lain, semua kelompok harus mendapatkan perlakuan yang sama dari negara, temasuk bagi mereka warga miskin perkotaan.

Namun faktanya di Indonesia, keberadaan pemerintah daerah masih jauh dari cita-cita di atas. Kepentingan masyarakat miskin kota kerap kali tidak diakomodasi oleh negara. Dalam banyak kasus, terutama di depan komunitas terbelakang, pemerintah justru sering alpa dalam mencegah tingginya angka putus 
sekolah dan angka kematian bagi mereka yang miskin (Hal ini terkonfirmasi dalam laporan terbaru Organisation for Economic Cooperation and Development OECD, yang menyebutkan bahwa Indonesia memiliki presentase angka putus sekolah tertinggi ke 2 di dunia). Bagi mereka yang miskin, pendidikan dan kesehatan hampir pasti jauh dari angan-angan. Tak ada otoritas yang lebih tinggi manapun yang akan membela kecuali pemerintah. Itu sebabanya, hal-hal yang menjadi masalah ini tidak boleh dilanjutkan.

Berangkat dari kondisi itu, penelitian ini menjadi penting dilakukan terutama untuk mencari faktor penyebab kegagalan peran negara dalam menjamin layanan pendidikan dan kesehatan bagi mereka masyarakat miskin kota. Pelacakan terhadap sumber kegagalan fungsi negara di berbagai pemerintahan daerah sangat diperlukan, mengingat keberpihakan pemerintah, penegakan keadilan sosial, serta menjamin pemerataan, itulah ukuran dari negara sejahtera yang saat ini sedang getol-getolnya hendak ditegakkan.

\section{Metodologi Penelitian}

Studi ini menggunakan jenis penelitian kualitatif yang menjelaskan bagaimana kemiskinan yang terbentuk di kawasan Tempat Pembuangan Akhir Sampah Talang Gulo, kota Jambi. Penelitian ini menggunakan pendekatan studi kasus yang bersifat intrinsic case study yang bertujuan untuk mengetahui lebih mendalam tentang proses keberpihakan pemerintah kota Jambi terhadap mereka yang selama ini jauh dari jangkauan program pemerintah. Lokasi ini sebagai lokasi penelitian karena beberapa alasan. Pertama, kawasan Tempat Pembuangan Akhir Sampah Talang Gulo, Kota Jambi merupakan daerah pinggiran perkotaan yang rentan akan kemiskinan. Kedua, warga kawasan Tempat Pembuangan Akhir Sampah Talang Gulo, Kota Jambi sejak dulu dikenal sebagai warga yang miskin.

Dalam rangka pengumpulan data peneliti melakukan pengamatan terlibat dengan cara melakukan interaksi langsung dengan masyarakat setempat berupa wawancara mendalam dan observasi partisipan dengan demikian peneliti dapat mencermati bagaimana pola keberpihakan yang terjadi dalam pemenuhan hak warga miskin kota dan bagaimana masyarakat setempat menggunakan arena TPA sebagai tempat satu-satunya sumber penghasilan mereka. Berikut ini merupakan beberapa langkah pengumpulan data yang dilakukan: Desk study Langkah ini diambil untuk membantu menemukan, merumuskan, dan memetakan relasi-relasi yang terjadi di dalam masyarakat TPA selama proses pemenuhan hak-hak mereka dan dapat membantu penulis dalam mengkerangkai realitas yang terjadi dengan menggunakan data-data pendukung yang ada. Data dari desk study merupakan data sekunder mengenai pola relasi, kemiskinan, kebijakan warga miskin perkotaaan yang diperoleh melalui buku, media massa, laporan penelitian, jurnal, majalah, dan sebagainya.

Field study Langkah selanjutnya dalam pencarian data adalah field study untuk menemukan data primer yang dibutuhkan. Melalui field study, peneliti berinteraksi langsung dengan masyarakat yang sedang diteliti sehingga diharapkan dapat melihat realitas yang terjadi dengan lebih jelas, terutama mengenai bagaimana interaksi atau pola hubungan antar-warga. Proses tersebut tentu hanya dapat diketahui setelah peneliti melakukan pengamatan atau observasi langsung bersama 
informan ataupun dengan cara melakukan wawancara dengan beberapa informan yang peneliti anggap akan memberikan informasi yang mendukung penelitian ini. Adapun informan yang akan diwawancarai dalam penelitian ini adalah tokoh-tokoh penting di kawasan Tempat Pembuangan Akhir Sampah Talang Gulo, Kota Jambi. Langkah-langkah dalam analisis data yang digunakan dalam penelitian ini mengikuti Creswell (2007) yakni pertama, peneliti mengorganisir informasi yang ditemukan di lapangan, dalam hal ini peneliti bertindak sebagai pengumpul informasi melalui pembacaan terhadap berbagai literatur dan wawancara dengan informan serta observasi mendalam yang dilakukan di kawasan Tempat Pembuangan Akhir Sampah Talang Gulo, Kota Jambi yang merupakan lokasi tempat tinggal masyarakat miskin perkotaan yang menjadi kajian penelitian. Setelah data yang dibutuhkan terkumpul maka langkah kedua adalah membaca keseluruhan informasi yang telah diperoleh dan memberi kode pada setiap hasil amatan untuk memudahkan ketika dilakukan analisis. Dan tahapan ketiga adalah membuat suatu uraian terperinci mengenai kasus yang terjadi beserta konteks terjadinya suatu peristiwa. Keempat, peneliti menetapkan pola kebijakan pemerintah terhadap warga miskin perkotaan di kawasan Tempat Pembuangan Akhir Sampah Talang Gulo, Kota Jambi melalui pembacaan terhadap aktor-aktor yang saling berinteraksi di lokasi penelitian (kawasan TPA). Kelima, peneliti melakukan interpretasi terhadap fenomena yang terjadi dan selanjutnya menyajikan hasil intrepetasi atas data yang diperoleh secara naratif di dalam bentuk tulisan.

\section{Hasil Penelitian}

Kota Jambi dengan luas wilayah $\pm 205.38 \mathrm{~km}^{2}$ (berdasarkan UU No. 6 tahun 1986), terletak pada kordinat : Koordinat tersebut menunjukkan keberadaan Kota Jambi yang terletak di tengah-tengah pulau Sumatera. Secara geomorfologis Kota Jambi terletak di bagian Barat cekungan Sumatera bagian selatan yang disebut SubCekungan Jambi, yang merupakan dataran rendah di Sumatera Timur.

Ditilik dari topografinya, Kota Jambi relatif datar dengan ketinggian 0-60 m diatas permukaan laut. Bagian bergelombang terdapat di utara dan selatan kota, sedangkan daerah rawa terdapat di sekitar aliran Sungai Batanghari, yang merupakan sungai terpanjang di pulau Sumatera dengan panjang keseluruhan lebih kurang $1.700 \mathrm{~km}$, dari Danau Atas-Danau Bawah (Sumatera Barat) menuju Selat Berhala (11 km yang berada di wilayah Kota Jambi) dengan kelebaran lebih kurang $500 \mathrm{~m}$. Sungai Batanghari membelah Kota Jambi menjadi dua bagian di sisi utara dan selatannya. (Jambi dalam angka, 2015).

Sementara itu, terkait masalah kemiskinan, angka kemiskinan di Kota Jambi masih tergolong tinggi. Selama periode September 2016-Maret 2017, jumlah penduduk miskin di daerah perkotaan mengalami peningkatan 4,29 ribu orang (dari 116,33 ribu orang pada September 2016 menjadi 120,62 ribu orang pada Maret 2017), sedangkan di daerah perdesaan berkurang 8,55 ribu orang (dari 174,48 ribu orang pada September 2016 menjadi 165,93 ribu orang pada Maret 2017). Salah satu faktor yang menciptakan tendensi tersebut adalah kondisi perkotaan yang ditandai dengan minimnya lapangan pekerjaan. Kondisi semacam ini membuat penduduk perkotaan sulit melakukan kegiatan produktif. Akhirnya, mereka mengadu nasib 
dengan bekerja mengisi sektor-sektor informal di perkotaan. Kesejahteraan kemudian menjadi persoalan bagi mereka warga kota yang tinggal di pinggiran.

Dalam hal ini, kemiskinan acapkali divonis sebagai penyakit sosial ekonomi yang perlu dijauhi. Ada juga yang menyebutkan kemiskinan sebagai borok pembangunan yang perlu segera diobati. Ada pula beberapa pihak yang menyatakan kemiskinan identik dengan nasib atau suratan takdir yang ditentukan oleh Allah Yang Maha Kuasa. Meski demikian, pada kesempatan ini perlu disepakati bahwa kemiskinan merupakan realitas sosial yang bisa menimpa suatu kelompok masyarakat tertentu karena dilatarbelakangi berbagai akar permasalahan. Oleh karena itu, kemiskinan bukanlah sesuatu fakta sosial yang secara mendadak muncul begitu saja akibat faktor penyebab tunggal. Belenggu kemiskinan bersifat multi dimensional dan cenderung membentuk siklus yang secara berkesinambungan dan terus berlanjut sehingga sulit diputus pada fase manapun yang dilalui.

Pemahaman terhadap kemiskinan tidak boleh hanya didasari pada ketiadaan, kekurangan dan keterdesakan ekonomi semata. Lebih penting lagi dipahami bahwa kemiskinan juga merupakan perwujudan dari realitas kegagalan seseorang atau sekelompok orang dalam memenuhi: kebutuhan hidup, hak dasar, keadilan dalam perlakukan hukum, kesetaraan gender dan kehidupan yang beradab dan bermartabat. Kaum miskin dimanapun berada selalu menduduki posisi yang marginal. Eksistensi diri mereka senantiasa terpinggirkan. Aspirasi yang dipunyai kaum miskin tak tersuarakan karena keputusan yang diambil lebih baik memilih sikap diam. Kemiskinan tidak boleh dibiarkan berlangsung terus karena akan menjadi beban yang semakin berat dan berlarut bagi masyarakat. Sebelum memulai kebijakan pro masyarakat miskin /pemberdayaan, kita perlu mengidentifikasi secara cermat akar permasalahan yang melatarbelakangi beserta kekuatan pengaruh yang ditimbulkan. Konstruksi hubungan antar beragam akar permasalahan juga perlu dipahami secara mendalam guna memudahkan perumusan solusi kemiskinan yang strategis direncanakan. Menurut hasil penelitian dari Santosa dan Priyono (2009) terungkap bahwa akar permasalahan kemiskinan memiliki konstruksi hubungan yang saling bertautan. Untuk itu, masalah jamin menjamin kesejahteraan masyarakat sudah merupakan tanggung jawab yang semestinya dipenuhi oleh pemerintah sesuai dengan amanat undang-undang dasar. Indonesia yang merupakan negara demokrasi memiliki tantangan besar dalam menjawab persoalan kemiskinan dan meningkatkan kesejahteraan masyarakat. termasuk bagi pemerintah Kota Jambi. Untuk mewujudkan kesejahteraan bagi masyarakat miskin perkotaan tidak bisa dilepaskan dari keberadaan dan kinerja kebijakan sosial (social policy) yang dikembangkan oleh pemerintah (Midgley, J. Eooo, 2008). Artinya, instrumen kebijakan secara khusus dirancang dan diterapkan untuk meningkatkan kesejahteraan masyarakat. Adapaun kesejahteraan dapat dimaknai secara berbeda-beda. Menurut UU no 11 tahun 2009, kesejahteraan sosial adalah kondisi terpenuhinya kebutuhan material, spiritual, dan sosial warga negara agar dapat hidup layak dan mampu mengembangkan diri, sehingga dapat melaksanakan fungsi sosialnya. Ukuran suatu negara sejahtera tidak ditentukan oleh Produk Nasional Bruto (PNB). Mengutip dari Vandana Shiva, kenaikan PNB tidak berarti menaikkan kekayaan atau kesejahteraan masyarakat. Hal ini karena PNB tidak menghitung biaya dari beban ekologi dan hilangnya sumber penghidupan penduduak pinggiran (khususnya perempuan) yang 
dihasilkan dari aktivitas investor. Namun bagi perusahaan yang berada di dalam skema welfare pluralism (Sinopsis Fisipol Research Days 2014), kesejahteraan dimanifestasikan dalam bentuk corporate social responsibility yang kemudian dioperasionalisasikan melalui program community development sebagai upaya peningkatan kesejahteraan. Di tengah banyaknya ragam macam pemahaman terhadap kesejahteraan, dalam penelitian ini, kesejahteraan dilihat dari kacamata hak asasi manusia yang menempatkan kesejahteraan sebagai hak bagi setiap warga negara. Hak atas kesejahteraan telah hadir pada 1936 melalui konstitusi USSR yang menjamin hak atas pendidikan, hak pekerjaan, mendapat bantuan ketika sakit dan disability. Apabila hak-hak dasar seperti kebutuhan pangan, kesehatan, pekerjaan dan pendidikan tidak terpenuhi, maka dapat dikatakan bahwa seseorang dalam kondisi miskin. Hak kesejahteraan dikokohkan dalam Deklarasi Hak Asasi Manusia di tahun 1948, dan kemudian diatur dalam kovenan internasional mengenai hak ekonomi sosial dan budaya (International Covenant on Economic, Social and Cultural Rights/ICESCR). Pembahasan kerangka hak asasi manusia penting merujuk pada perjanjian-perjanjian hak asasi manusia, sebagai upaya untuk melakukan litigasi, monitoring, akuntabilitas dan strategi advokasi sesuai dengan yang tercantum di dalam perjanjian (Sofia Monsalve Suarez, 2012: 242). Di dalam hak ekonomi sosial dan budaya, telah dijamin mengenai hak atas pendidikan dan kesehatan dimana setiap orang berhak untuk memperoleh standar hidup yang layak bagi dirinya sendiri dan keluarganya. Salah satu indikator kesehatan misalanya yaitu tempat tinggal yang dapat melindungi diri dari ancaman kesehatan maupun fisik bangunan.

Artinya, kesejahteraan bukan hanya diukur dari hunian dan pekerjaan, tetapi juga dilihat dari kesehatan. Pasal 25 (1) Deklarasi Universal Hak Asasi Manusia menyatakan : "Setiap manusia mempunyai hak atas standar kehidupan yang cukup, bagi kesehatan dirinya sendiri dan keluarganya, yang mencakup makanan, tempat tinggal, pakaian dan pelayanan kesehatan serta pelayanan sosial yang penting. Hak atas kesehatan dimaknai sebagai hak inklusif yang luas, mencakup tidak hanya pelayanan kesehatan yang tepat dan memadai, namun juga mencakup faktor-faktor peranan kesehatan, misalnya akses terhadap air minum sehat dan sanitasi yang memadai. Perhatian harus diberikan untuk memastikan bahwa warga pinggiran kota yang tidak beruntung dan termarjinalisasi, termasuk pengumpul sampah perempuan, mempunyai akses yang sama terhadap kesemua itu.

Ketika berbicara hak atas kesehatan, maka tidak bisa dilepaskan dari hak atas pendidikan. Pendidikan memiliki arti penting bagi masyarakat dan (terutama) pengumpul sampah yang menggantungkan hidup dari pengolahan sampah. Pemerintah Kota dalam hal ini memiliki kewajiban untuk menghormati, menjaga dan memenuhi hak atas kesehatan dan pendidikan warga kota. Pemerintah kota juga harus memenuhi dan memfasilitasi akses berkelanjutan terhadap penggunaan sarana prasarana pendidikan dan kesehatan siapa saja yang menggunakannya sesuai dengan gagasan hak asasi manusia pada dua aspek tersebut.

Perubahan kawasan perkotaan menjadi kawasan perdagangan dan jasa di banyak tempat memunculkan konflik dan pelanggaran HAM. Tersingkirkanya hakhak masyarakat dilakukan atas nama kapital dalam praktik globalisasi (Hendrik Siregar. 2014: 63). Bahkan White dan Wiradi menyebut bahwa tidak satupun proses 
perubahan arah pembangunan kota di Jawa pada masa pra-kolonial maupun kolonial berlangsung secara damai karena adanya persoalan ketidakmerataan distribusi. Dalam istilah setempat, kekerasan yang disebut perang warga selalu terjadi dalam proses perubahan-perubahan itu.

Di zaman pemerintah orde baru misalnya dengan kebijakan pembangunan neoliberalismenya mengubah tanah pertanian untuk pembangunan sektor lain seperti perkebunan sawit, penambangan, ataupaun pembangunan perkotaan dengan model perampasan tanah. Penetapan kawasan konservasi dan taman nasional hanya modus untuk membatasi akses masyarakat akan sumber daya. Fauzi menjelaskan model perampasan tanah dan kekayaan alam dimulai dari adanya negaranisasi atau nasionalisasi tanah dan kekayaaan alam kepunyaan penduduk, dan atas dasar klaim negara itu, pemerintah memberikan ijin-ijin dan hak-hak pemanfaatan di atas bidang tanah termaksud untuk perusahaan bermodal besar atau proyek-proyek pembangunan, baik yang dimiliki badan usaha swasta maupun pemerintah.

Jelasnya, aktivitas korporasi dalam lingkungan komunitas miskin di negara berkembang menghasilkan kekerasan HAM, baik kekerasan ekonomi, sosial budaya, maupun kekerasan terhadap hak sipil dan politik. Globalisasi menjadikan korporasi memiliki kekuasaan yang kuat, termasuk mengontrol pemerintah. Jernej Letnar Cernic menyebutkan kemungkinan pelanggaran-pelanggaran HAM yang dilakukan korporasi. Diantaranya yaitu penyiksaan, diskriminasi rasial, genosida, pemaksaan dan buruh anak-anak, perbudakan, degradasi lingkungan, penyingkian warga miskin dan kekerasan lain yang berhubungan dengan komunitas lokal. Lebih lanjut, Cernic menjelaskan bahwa perusahaan yang bergerak dalam sektor apapun berkontribusi terhadap pelanggaran HAM, khususunya terkait akses orang miskin pada pendidikan dan kesehatan.

Dalam kondisi yang seperti itu, dengan berbagai indikator yang dikuantifikasikan, pemerintah seringkali memberikan cap "miskin dan tidak produktif" pada sebuah masyarakat yang sebenarnya tidaklah miskin bahkan sangat produktif. Jadi, yang perlu diingat bahwa kesejahteraan memiliki kontekstualisasi yang selalu berbeda dalam sebuah masyarakat. Artinya, kesejahteraan sejak awal memang telah melekat dalam konteks sosial, ekonomi, politik, kultural sebuah masyarakat. Tidak ada ukuran pasti yang bisa disamaratakan begitu saja tentang kesejahteraan sebuah masyarakat. Adapun di bagian ini, peneliti akan menguraikan bagaimana makna kesejahteraan diciptakan melalui perangkat kebijakan, dalam hal ini adalah kebijakan pengaman warga miskin kota.

Sebelum itu kita mulai dari satu pertanyaan. sebagaimana pertanyaan kritis Stiglitz, Sen, dan Fitoussi (2011: 24) terhadap indikator PDB, "Prinsip keberlanjutan menyuguhkan tantangan apakah taraf kesejahteraan yang ada sekarang bisa dilestarikan untuk generasi-generasi mendatang?". Indikator kesejahteraan yang disuguhkan dari PDB mengakibatkan daerah/negara hanya menggenjot kemampuan ekonomi melalui produksi yang sebesar-besarnya. Namun, kenyataan bahwa dalam proses produksi tersebut merusak lingkungan, alam, dan sumber daya alam yang sebenarnya merupakan penopang kehidupan banyak orang di masa depan diabaikan begitu saja.

Dari analisis diatas, kita bisa merefleksikan pertanyaan kritis, jika PDB per kapita saja tidak bisa dianggap sebagai indikator kesejahteraan, apalagi PAD yang 
bukan merupakan hitungan kapasitas produski per orang di sebuah daerah. Dalam titik tertentu, pengejaran PAD biasanya digerakan dalam konteks politik sehari-hari sebuah daerah, dimana para legislatornya (DPRD) memiliki kepentingan peningkatan PAD yang besar.

Selain itu, lapangan pekerjaan menjadi kunci kesejahteraan, hanya ketika lapangan kerja itu benar-benar menyerap tenaga kerja dan bukan malah menutup lapangan kerja lain yang lebih besar. Asumsi penulis seluruh ilmuwan yang bergelut dalam kajian kesejahteraan (dan kemiskinan) akan sepakat dengan argumen ini. Untuk itu, perlu kejelian tersendiri ketika sebuah kebijakan atau proyek kesejahteraan itu menggunakan argumen membuka lapangan pekerjaan. Jika kita tidak kritis, membuka "lapangan kerja" yang lebih besar hanyalah jargon untuk menutupi sebuah kebijakan yang sejatinya malah memiskinkan, karena mengancam bahkan menghapus lapangan pekerjaan yang lebih luas lainnya.

Kendatipun kita secara eksplisit telah "mengharamkan" economic growth oriented, namun dalam banyak hal menunjukkan bahwa pendewaan terhadap pembangunan berupa angka-angka ini tetap menjadi target prioritas yang justeru mematikan kreativitas dalam membangun kota ini menjadi lebih baik. Pembiaran terhadap kaum miskin untuk menghadapi sendiri berbagai persoalan hidup tentulah merupakan bentuk layanan buruk sektor perkotaan. penulis yakin banyak diantara kita hafal dan paham berapa angka pertumbuhan ekonomi yang dari tahun ke tahun menjadi impian para perencana dan pelaksana berbagai proyek pembangunan yang bersifat tidak pro poor apalagi pro poorest (ul-Haq, 1983). Kita menjadi terbiasa tatkala mendengar kaum miskin di perkotaan diklaim sebagai penduduk liar hingga membiarkan mereka terjebak dalam jerat persoalan pengangguran. Kita merasa awam mungkin karena kelalaian memikirkan berapa kebutuhan air bersih untuk warga miskin, yang terpaksa mereka beli walau harganya setara premium. Tidak hanya itu, kealpaan kita juga terkait ketidaktahuan tentang kebutuhan kaum miskin di perkotaan untuk memaknai kesejahteraan yang berdasar pemahaman mereka.

\section{Sejahtera itu Tercukupi Kebutuhannya}

Penulis akan mengawali cerita ini dengan menjelaskan seperti masyarakat masyarakat miskin yang ada TPA Talang Gulo dalam memenuhi kebutuhannya. Sejak lama telah terjadi hubungan mutualisme antara warga talang Gulo dengan TPA. Bagi mereka, tumpukan sampah merupakan sumber kehidupan sehari-hari masyarakat disana. Kondisi ini disebabkan karena pola pembangunan kota yang belum menyentuh warga miskin kota, dimana kelangsungan hidup mereka akhirnya sangat ditentukan keberadaan sampah itu sendiri. Bagi para warga di sana, hidup di tengah sampah merupakan anugerah. Di tengah tidak adanya ruang lapangan pekerjaan baru, sampah bagi mereka merupakan satu-satunya alternatif untuk melangsungkan hidup. Sampah yang didapat memiliki tujuan yang berbeda-beda. Jika warga menumpuk barang-barang sampah tertentu di sebagain tempat tinggalnya, itu berarti mereka sedang mempersiapkan kebutuhan makanan seharihari untuk jangka panjang. Artinya, sampah yang dihasilkan dari pencarian tidak dijual, namun ditimbun di rumah dalam bentuk . Meski demikian, tidak menutup kemungkinan ada warga yang menjual sampahnya jika ada kebutuhan lain di luar kebutuhan makanan pokok. Para warga di sana, terutama para ibu rumah tangga, 
sebagian besar berfikiran bahwa menyimpan sampah di rumah merupakan cara menjaga stabilitas pangan rumah tangga dalam waktu yang lama. Keberadaan sampah "berharga" di rumah sama artinya dengan ketercukupan bahan makanan selama satu tahun ke depan.

Akan tetapi, situasi seperti ini tentu perlu ditanggapi serius oleh pemerintah kota. Di beberapa wilayah TPA yang merupakan tumpukan sampah tentu memiliki masalah dengan kebersihan, karena kapan saja penyakit dapat muncul dan bisa merusak (merubuhkan) fisik para warga. Jika layanan kesehatan tidak dijamin, maka kemiskinan yang diderita mereka sungguhlah makin mendalam.

\section{Sejahtera versi warga miskin kota}

Sub-judul ini kesannya memang terlalu meromantisir kondisi warga miskin perkotaan, namun kenyataan relasi saling berbagi ini masih terpelihara hingga sekarang. Penulis seringkali melihat, orang makan (pagi/siang/malam) di rumah tetangga merupakan hal yang lumrah. Bahkan, setiap ada tamu atau tetangga yang tidak sengaja berkunjung ke sebuah keluarga, maka keluarga itu akan menawarkan makan di rumahnya. Berbagi makanan tidak semata menjadi sebuah kebiasaan, namun sudah menjadi cara mereka hidup. Ketika orang memperlakukan tamu dengan cara demikian, hal itu karena orang tersebut percaya bahwa tentangga/tamunya itu juga memperlakukan secara sama jika dirinya menjadi tamu. Tetapi yang perlu diingat, bahwa hubungan ini bukan relasi transaksional, dimana ada sesuatu yang dipertukarkan. Relasi ini cair, dan sudah melekat dalam kehidupan mereka bersama sejak beberapa generasi lamanya.

Tidak hanya itu, jika sebuah keluarga memiliki makanan tertentu, misalkan jagung/ketela rebus, mereka akan berbagi dengan tetangganya. Sekilas relasi tolong menolong ini terlalu sederhana jika dianggap sebagai sebuah makna kesejahteraan. Namun, kenyataan tolong menolong ini menjadi makna sejahtera jika secara cermat dihadapkan pada keadaan tiadanya pola saling berbagi atau tolong menolong semacam itu. Sebuah keluarga menceritakan kepada peneliti pengalaman hidupnya.

"Kami sudah tinggal di sini selama 6 tahun. Dulu bapak pernah diare selama 6 hari. Bukan perkara sakitnya yang menjadi masalah utama, namun tidak bekerja selama 6 hari itu kan berarti tidak mendapatkan penghasilan. Ekonomi keluarga menjadi kacau balau. Beda jika hidup di desa, sakit 6 hari dan digunakan untuk istirahat, kita masih bisa makan. Hidup di kota rasanya semua serba uang, tidak ada saling membantu antar tetangga. Beda dengan di desa, mau makan ketela tidak perlu membeli karena sudah banyak tetangga yang berbagi”.

Dari cerita ini penulis hendak katakan, para warga ini sadar betul bahwa kesejahteraannya bukan semata persoalan kepemilikan uang, namun adanya relasi dimana antar orang satu dengan yang lainnya saling tolong menolong di saat yang lainnya sedang membutuhkan. Terutama terkait keberadaan sikap keberpihakan pemerintah pada mereka.

Alhasil, kemiskinan masyarakat di perkotaan merupakan realitas sosial yang memerlukan perhatian serius dari berbagai pihak terkait. Konstruksi akar 
permasalahan kemiskinan di perkotaan suatu ketika membentuk jaring laba-laba yang sulit diputuskan. Namun bukan berarti tidak ada jalan untuk meretas jalan ke arah kehidupan yang lebih baik. Peningkatan faktor-faktor non ekonomi, seperti : kesehatan dan sanitasi, pendidikan dasar dan ketrampilan dasar untuk dapat survive serta kebutuhan fisik minimum sangat perlu untuk diperhatikan. Penulis menekankan pada salah satu hal penting bagi penanganan kaum miskin kota pada akses pendidikan agar mereka survive. Pengalaman pejuang kemikinan di Kamboja mengembangkan pendidikan patut mendapatkan apresiasi. Di tengah suasana pasca perang yang tidak kondusif masih selalu ada jalan untuk meretas kemiskinan. Di masa yang akan datang, kelihatannya knowledge base for reducing poverty ini masih akan terus relevan. Kerjasama yang integratif diperlukan untuk merealisasi solusi strategis bagi reduksi persoalan kemiskinan di perkotaan. Dalam hal partisipasi ini masyarakat hendaknya perlu dilibat-kan dalam tiap proses pembangunan yaitu (1) identifikasi permasalahan, dimana masyarakat bersama para perencana maupun pemegang otoritas kebijakan tersebut mengidentifikasi-kan persoalan dalam diskusi kelompok, brainstorming, identifikasi peluang, potensi dan hambatan. (2) proses perencanaan, dimana masyarakat dilibatkan dalam penyu-sunan rencana dan strategi yang berdasar kepada hasil identifikasi. (3) pelaksanaan proyek pembangunan, (4) evaluasi, yaitu masyarakat dilibatkan untuk menilai hasil pembangunan yang telah dilakukan, apakah pembangunan memberikan hasil guna (kemanfaatan bagi masyarakat) ataukah justru masyarakat dirugikan dengan proses yang telah dilakukan, merupakan inti dari proses evaluasi ini, (5) mitigasi, yakni kelompok masyarakat dilibatkan dalam mengukur sekaligus mengurangi dampak negatif pembangunan, (6) monitoring, tahap yang dilakukan agar proses pembangunan yang dilakukan dapat dilakukan. Dalam tahap ini juga dimungkinkan adanya penyesuaian-penyesuaian yang berkaitan dengan situasi dan informasi terakhir dalam pembangunan yang telah dilaksanakan. Dengan demikian, partisipasi adalah bagaimana keikutsertaan masyarakat secara aktif dalam tahap-tahap pembangunan di daerahnya. Peran serta masyarakat secara aktif dalam pembangunan mengidentifikasikan adanya partisipasi yang tinggi dari masyarakat. Dengan adanya partisipasi maka diharapkan pembangunan akan berjalan dengan baik.

Pada dasarnya, kepedulian untuk mewujudkan masyarakat kota yang lebih baik dan terbebas dari kemiskinan telah berlangsung selama ini melalui berbagai upaya yang dinilai strategis baik oleh warga masyarakat sendiri, maupun pemerintah, dan pihak-pihak yang lain, seperti: LSM, swasta dan bahkan sebagian pesantren. Upaya yang dilakukan beragam dan terus bergulir seperti yang ditawarkan pemerintah antara lain: Kredit Ketahanan Pangan (KKP), Jaring Pengaman Sosial (JPS), Bantuan Langsung Tunai (BLT), Raskin, Askeskin, P2KP dan terakhir PNPM mandiri perkotaan dan masih banyak program lain. Kesemua program tersebut memang diakui sudah memberikan kontribusi yang tidak kecil terhadap tahap awal pemberdayaan masyarakat. Sayang bahwa di balik keberhasilan yang dicapai, perlu dicatat dan direnungkan kembali bahwa aneka bentuk program itu belum optimal berhasil menyentuh semua kepentingan lapisan masyarakat khususnya kaum miskin, yang seyogyanya perlu segera mendapat prioritas. 


\section{Simpulan}

Pengalaman ini membahas beberapa faktor kegagalan program penanggulangan kemiskinan perkotaan di Jambi. Berbagai temuan di lapangan menunjukkan bahwa negara telah gagal dalam menyelenggarakan jaminan sosial sebagai salah satu strategi untuk mengatasi masalah kesejahteraan masyarakat, terutama bagi mereka yang hidup di bawah garis kemiskinan. Ada dua permasalahan utama yang memberikan kontribusi terhadap kegagalan pemerintah di dalam menjalankan tugasnya menjaga kesejahteraan masyarakat melalui jaminan sosial. Pertama, berbagai macam program yang dilaksanakan tidak didistribusikan tepat sasaran. Seringkali individu yang dianggap miskin oleh pemerintah, justru merupakan kelompok mampu menurut versi masyarakat. Hal tersebut dipengaruhi oleh minimnya pengetahuan sosial kultural birokrasi pemerintah. Birokrasi pemerintah seringkali bertindak sendiri tanpa memperhatikan aspirasi masyarakatnya. Kedua, pendekatan dan strategi yang digunakan negara di dalam menyelenggarakan jaminan sosial cenderung bersifat formal, terstruktur, dan mengabaikan nilai-nilai sosial yang hidup di dalam masyarakat. Jaminan sosial dilenggarakan dengan mekanisme dan sistem yang dibangun secara mandiri oleh pemerintah, dengan keterlibatan sedikit masyarakat di dalamnya. Kondisi tersebut mempengaruhi penilaian dan kepercayaan masyarakat terhadap program-program yang sedang dilaksanakan oleh pemerintah.

Kegagalan jaminan sosial yang dilaksanakan oleh negara meninggalkan ketidaksejahteraan masyarakat. Jumlah penduduk miskin cenderung stabil sementara akses terhadap kesejahteraan semakin mahal. Artinya, ada kesimpulan tentang dibutuhkannya kajian ekstra dalam upaya penanggulangan kemiskinan perkotaan.

Kajian ini sangat merekomendasikan analisis tambahan dari Pemerintah Kota Jambi untuk secara mendalam memahami apa yang dimaksud dengan kemiskinan perkotaan, karena karakteristiknya sangat berbeda dengan kemiskinan pedesaan. Strategi untuk penanggulangannya harus ditingkatkan, tidak hanya menggunakan indikator ekonomi tetapi juga indikator lain seperti sosial, budaya, politik, bisnis dan keterampilan teknis. Laporan ini pada dasarnya mendapat 3 data penting:

1) Adanya miskoordinasi antara Sektor Swasta, dan Pemerintah.

2) Penduduk miskin di kota Jambi tidak mendapatkan jaminan sosial yang baik untuk menjalankan hidup dengan baik.

3) Ada semacam budaya kemiskinan di Talang Gulo, yang terlihat dari sebagian masyarakat miskin di kawasan tersebut yang berfikir hidupnya cukup dengan cara seperti sekarang. Itu sebabnya anak-cucu merekapun jarang diberikan akses untuk mendapat pendidikan. Sehingga bukan tidak mungkin akhir dari cerita kemiskinan di Talang Gulo adalah kemiskinan yang struktural. 


\section{Daftar Pustaka}

Andre Bayo Ala, 1981. Kemiskinan dan Strategi Memerangi Kemiskinan, Yogyakarta: Liberty.

Barry J.L., et al. 1997. Digestive and metabolic effects of potato and maize fibres in human subjects. Br. J. Nutr, 77 (1): 33-46.

Barry, C., Morrison, C. M., \& Ellis, A. W. (1997). Naming the Snodgrass and Vanderwart pictures: Effects of age of acquisition, frequency, and name agreement. Quarterly Journal of Experimental Psychology A, 50, 560-585.

Barry, C., Morrison, C. M., \& Ellis, A. W. (1997). Naming the Snodgrass and Vanderwart pictures: Effects of age of acquisition, frequency, and name agreement. Quarterly Journal of Experimental Psychology A, 50, 560-585.

Creswell, John W, 1998, Qualitative Inquiry and Research Design: Choosing Among Five Tradition, USA: Sage Publication.

2009, Research Design:Qualitative, Quantitative and Mixed Methods Approaches, London: Sage Publication.

2012, Research Design: Pendekatan Kualitatif, Kuantitatif Dan Mixed, Yogyakarta:Pustaka Pelajar.

Executive Summary dalam Sinopsis Fisipol Research Days 2014.

Hendrik Siregar. 2014. Akhiri Cara Mudah Tambang Habisiss Hutan: Stop Izin Pinjam Pakai Hutan. Jurnal LandReform. Volume 1/Mei 2014.

Holland, J. L., Powell, A., \& Fritzsche, B. (1994). SDS professional user's guide. Odessa, FL: Psychological Assessment Resources, Inc.

Marsh, D dan Stoker, G, 2011, Teori dan Metode Penelitian Ilmu Politik, Bandung: Nusa Media.

Midgley, J. eooo. "The -Definition of soeial policy" dalam J. Midgley, M.B. Tracy dan M.Livermore (ed). The $\mathrm{H}$ andbook of social polfcy. sage publication. London, dikutip dari D. Triwibowo. Demokrasi Tanpa Kesejahteraan? Telaah dan Gagasan Bagi Reforma Kebijakan Sosial di Indonesia. Makalah pada Panel Gerakan Buruh di Bawah Tirani Modal dalam Konferensi Warisan otoritarianisme: Demokrasi Indonesia dan Tirani Modal, 5 Agustus 2oo8, Depok.

Sen, A., 1981. Poverty and Famines: An Essay on Entitlement and Deorication, Oxford: Clarendon Press. 
Sofia Monsalve Suarez. 2012. The Human Rights Framework in Contemporary Agrarian Struggle. The Journal of Peasant Studies. DOI: 10.1080/03066150.2011.652950.

Word Bank (1999). Coporate Governance: Framework for Implementation, Overview. www.wordbank.org.pp.5

World Bank (2002) Poverty in Pakistan: Vulnerabilities, Social Gaps, and Rural Dynamics. Washington, D.C.: World Bank.

Yogi, S dan Iksan, M, (2006) Standar Pelayanan Publik di Daerah, Penerbit PKKOD-LAN, 
